\title{
ANALISIS FAKTOR-FAKTOR YANG MEMPENGARUHIPERMINTAAN DAGING SAPI DI PROVINSI LAMPUNG
}

\author{
Puradireja R.H. ${ }^{1}$, Herlina L. ${ }^{2}$, Arief H. $^{2}$ \\ ${ }^{1}$ Program Pascasarjana Fakultas Peternakan, Universitas Padjadjaran \\ Jl. Raya Bandung Sumedang Km 21, Jatinangor Sumedang \\ ${ }^{2}$ Departemen Sosial Ekonomi Pembangunan Peternakan, Fakultas Peternakan, \\ UniversitasPadjadjaran \\ Jl. Raya Bandung Sumedang Km 21, Jatinangor Sumedang \\ Email: rino14001@mail.unpad.ac.id \\ (Diterima 06-06-2021; Disetujui 05-07-2021)
}

\begin{abstract}
ABSTRAK
Tujuan dari penelitian untuk mengetahui faktor-faktor yang mempengaruhi permintaan daging di Provinsi Lampung. Lokasi dipilih secara porposive (sengaja) di Provinsi Lampung. Metode yang digunakan adalah deskriptif analitis. Penelitian ini menggunakan data sekunder yang dikumpulkan dari tahun 2014-2019. Data diperoleh dari Badan Pusat Statistik (BPS) dan instansi lainnya yg berhubungan dengan pangan. Berdasarkan hasil penelitian menunjukkan bahwa faktor-faktor yang mempengaruhi permintaan daging sapi di Lampung adalah harga daging sapi dan harga barang komplementer seperti harga telur ayam. Selain harga, konsumsi daging sapi di Indonesia, dan pertumbuhan ekonomi di Provinsi Lampung menjadi faktor penentu yang mempengaruhi permintaan dagin gsapi.
\end{abstract}

Kata Kunci : Daging sapi, Konsumsi, Permintaan

\section{ABSTRACT}

The purpose of this study was to determine the factors that influence the demand for meat in Lampung Province. The location was chosen positively (intentionally) in Lampung Province. The method used is descriptive analytical. This study uses secondary data collected from 2014-2019. Data obtained from the Badan Pusat Statistik and other agencies related to food. Based on the research results, it shows that the factors that influence the demand for beef in Lampung are the price of beef and the price of complementary goods such as the price of chicken eggs. Apart from price, beef consumption in Indonesia and economic growth in Lampung Province are the determining factors that affect beef demand.

Keywords : Beef, Consumption, Demand

\section{PENDAHALUAN}

Upaya yang dilakukan untuk mendukung program pemerintah mengenai percepatan pembangunan nasional yakni dengan peningkatan pendapatan. Sektor pangan merupakan harapan terpenting untuk meningkatkan pendapatan. Salah satu sektor pangan yang masih dianggap strategis hingga saat ini adalah usaha peternakan, pertanian, perkebunan dan perikanan. Sektor peternakan khususnya sapi potong diharapkan menjadi sektor yang mampu untuk meningkatkan pendapatan masyarakat. Pembangunan sektor peternakan merupakan upaya dalam 


\section{ANALISIS FAKTOR-FAKTOR YANG MEMPENGARUHIPERMINTAAN DAGING SAPI \\ DI PROVINSI LAMPUNG \\ Puradireja R.H., Herlina L., Arief H.}

pemenuhan kebutuhan protein hewani masyarakat, khususnya Provinsi Lampung dan nasional pada umumnya. Masyarakat umumnya sudah melakukan usaha di sektor sapi potong yang dapat dikembangkan di negara tropis seperti Indonesia. Penggemukan sapi di Indonesia umumnya masih menggunakan sistem tradisional dan masih berskala kecil.

Hasil penggemukan sapi potong harus menghasilkan daging yang mampu untuk memenuhi kebutuhan masyarakat secara nasional dan Provinsi Lampung secara regional. Setiap tahunnya jumlah penduduk di Indonesia meningkat, sejalan dengan pepertumbuhan penduduk dan kesadaran masyarakat akan pentingnya protein hewani maka kebutuhan daging sapi cendrung akan meningkat (Dwiyanto, 2018). Berdasarkan data tersebut seharusnya peternak lebih semangat untuk mengembangkan usaha peternakan yang memiliki potensi cukup bagus untuk meningkatkan perekonomian. Harapan peternakan ke depannya seharusnya bukan sebagai usaha sampingan, melainkan harus menjadi usaha utama karena sudah sangat jelas pemasaran dari produk yang akan dihasilkan.
Berdasarkan data kamar dagang Indonesia (KADIN), secara keseluruhan konsumsi daging sapi di Indonesia dengan jumlah penduduk sebanyak 269 juta jiwa baru mengkonsumsi daging sebanyak 2,6 kilogram per tahun. Angka tersebut masih tergolong rendah dibandingkan dengan negara lain seperti Filipina 3,1 kilogram per tahun,Malaysia 4,8 kilogram per tahun, Vietnam 9,9 kilogram per tahun. Konsumsi daging di dalam negeri dinilai harus ditingkatkan. Peningkatan konsumsi daging akan berpengaruh terhadap produktivitas peternak untuk menghasilkan daging. Jika dinilai dari aspek ekonomi sangat bagus karena meningkatkan pendapatan serta mensejahterakan peternak sapi potong. Jika peternak sejahtera maka iklim bisnis yang akan tercipta akan lebih baik ke depannya.

Peningkatan konsumsi daging menjadi kunci kesejahteraan peternak, namun peningkatan tersebut harus diimbangi dengan daya beli masyarakat terhadap daging sapi. Umumnya, harga daging sapi di Provinsi Lampung dinilai masih tinggi karena masyarakat menganggap daging sapi adalah daging yang eksklusif karena memiliki rasa, tekstur dan rasanya yang khas jika dibandingkan dengan daging lainnya. 
Salah satu penyebab rendahnya konsumsi daging masyarakat di Indonesia menjadi isu hangat yang perlu dikaji lebih mendalam melalui penelitian untuk menganalisis faktor-faktor yang mempengaruhi permintaan daging sapi di Provinsi Lampung.

Beberapa faktor yang digunakan untuk menganalisis permintaan daging, yaitu daging ayam, telur ayam, dan beras. Pemilihan daging dan telur ayam dikarenakan kedua faktor ini merupakan sumber protein hewani lainnya selain daging sapi. Sedangkan beras merupakan makanan pokok dari masyarakat Indonesia.

\section{METODE PENELITIAN}

Penelitian menggunakan data dan informasi yang relevan dari berbagai sumber. Data yang digunakan adalah data sekunder, yaitu data yang diperoleh dari instansi atau lembaga yang berhubungan dengan penelitian ini. Data diperoleh dari situs Badan Pusat Statistik (BPS), Dinas Perindustrian dan Perdagangan, dan instansi lainnya yang berkaitan dengan pangan. Data sekunder yang digunakan meliputi permintaan daging sapi, harga daging sapi, harga daging ayam, harga telur ayam, harga beras, jumlah penduduk lampung, konsumsi daging sapi di Indonesia, dan pertumbuhan ekonomi di Lampung. Data yang digunakan berupa data time series tahun 2014 hingga 2019.

Faktor-faktor yang mempengaruhi permintaan daging sapi dapat dianalisis menggunakan model permintaan statik analisis regresi (Fatmawati et al, 2016). Dengan memasukan variabel-variabel yang digunakan, maka bentuk persamaannya dapat ditulis ditulis sebagai berikut:

$\mathrm{Y}=\mathrm{X}_{1}+\mathrm{X}_{2}+\mathrm{X}_{3}+\mathrm{X}_{4}+\mathrm{X}_{5}+\mathrm{X}_{6}+\mathrm{X}_{7}$

Keterangan:

$\mathrm{Y}=$ Permintaan Daging Sapi

X1 = Rataan Harga Daging Sapi

X2 = Rataan Harga Daging Ayam

X3 = Rataan harga telur ayam Ras

X4 = Rataan Harga Beras

X5 = Jumlah Penduduk Lampung

X6 = Konsumsi Daging Sapi

X7 = Pertumbuhan Ekonomi

\section{HASIL DAN PEMBAHASAN \\ DATA PERTUMBUHAN PENDU- DUK LAMPUNG}

Peningkatan penduduk di suatu daerah menjadi faktor terpenting dalam peningkatan konsumsi pangan masyarakat. Peningkatan populasi, perbaikan kesejahteraan penduduk, penurunan harga, perubahan gaya hidup yang dibarengi dengan perkembangan 


\section{ANALISIS FAKTOR-FAKTOR YANG MEMPENGARUHIPERMINTAAN DAGING SAPI \\ DI PROVINSI LAMPUNG \\ Puradireja R.H., Herlina L., Arief H.}

perdagangan dan komunikasi global secara otomatis akan mendorong permintaan produk peternakan (Dwiyanto, 2008). Berdasarkan pendapat tersebut data pertumbuhan penduduk lampung dapat dilihat pada Tabel 1 .

\begin{tabular}{|c|c|c|}
\hline abel & \multicolumn{2}{|l|}{ Lampung/Tahun } \\
\hline Tahun & $\begin{array}{l}\text { Jumlah penduduk } \\
\text { (Juta Jiwa/Tahun) }\end{array}$ & $\begin{array}{c}\text { Pertumbuhan } \\
(\%)\end{array}$ \\
\hline 2014 & $8.026,2$ & \\
\hline 2015 & $8.167,8$ & 1,73 \\
\hline 2016 & $8.210,3$ & 0,52 \\
\hline 2017 & $8.295,3$ & 1,02 \\
\hline 2018 & $8.337,7$ & 0,5 \\
\hline 2019 & $9.007,8$ & 7,44 \\
\hline
\end{tabular}

Sumber: BPS 2015

Berdasarkan Tabel 1. Pertumbuhan penduduk di Provinsi Lampung mengalami kenaikan rata-rata sebesar 2,24\%/tahun. Pertumbuhan penduduk yang terus meningkat harus diiringi dengan peningkatan kualitas sumber daya manusia. Peningkatan kualitas dapat dilakukan seperti, peningkatan taraf hidup melalui pendidikan, penerapan pola hidup bersih dan sehat, kesadaran pentingnya memakan makanan yang bernilai gizi tinggi yaitu pangan protein hewani. Harapannya ketika kualitas kehidupan manusia terus ditingkatkan maka nantinya akan meningkatkan pola konsumsi daging masyarakat.

\section{PERKEMBANGAN POPULASI SAPI POTONG DI PROVINSI LAMPUNG}

Sapi potong merupakan ternak yang sudah cukup familiar bagi masyarakat di Provinsi Lampung. Masyarakat biasanya menjadikan sapi potong sebagai tabungan untuk keperluan pendidikan anak, keperluan mendesak atau keperluan lain yang sifatnya insidental atau fundamental. Data peningkatan populasi serta produksi daging sapi di Provinsi Lampung dapat dilihat pada Tabel2.

Tabel 2 Populasi Sapi Potong/Tahun dan Jumlah Produksi Daging Sapi/Tahun

\begin{tabular}{ccc}
\hline Tahun & $\begin{array}{c}\text { Populasi sapi } \\
\text { potong } \\
\text { (ekor/tahun) }\end{array}$ & $\begin{array}{c}\text { Produksi daging } \\
\text { (ton/tahun) }\end{array}$ \\
\hline 2017 & $8.295,3$ & 1,02 \\
2018 & $8.337,7$ & 0,5 \\
2019 & $9.007,8$ & 7,44 \\
2014 & 587.827 & 14.326 \\
2015 & 653.537 & 12.337 \\
2016 & 665.224 & 12.609 \\
2017 & 674.928 & 12.999 \\
2018 & 827.217 & 13.332 \\
2019 & 819.600 & 14.326 \\
\hline
\end{tabular}

Sumber: BPS, 2015

Daging sapi memiliki manfaat yang sangat besar dalam memenuhi kebutuhan gizi berupa protein hewani. Daging sapi merupakan produk ternak yang merupakan sumber protein hewani. Daging sapi merupakan bahan pangan yang mengandung gizi yang dibutuhkan oleh tubuh manusia untuk pertumbuhan dan kesehatan. Protein dari daging sapi sangat penting karena mengandung semua asam amino esensial termasuk 
yang mengandung mineral $\mathrm{S}$ yang tidak dimiliki oleh protein nabati dan sangat dibutuhkan untuk pertumbuhan dan mudah dicerna. Selain itu, daging sapi juga merupakan sumber utama mineral $\mathrm{Ca}$, P, Zinc, Fe serta vitamin B2, B6 dan B12 yang penting bagi tubuh manusia (Talib dan Yudi, 2008).

Data pada Tabel 2 menunjukkan bahwa peningkatan jumlah sapi potong tidak selaras dengan peningkatan produksi daging. Pada tahun 2019 jumlah populasi sapi potong sebanyak 819.600 ekor/tahun, namun hanya mampu menghasilkan produksi daging sebanyak 14.326 ton/tahun setara dengan tahun 2014 dengan jumlah populasi sapi 587.827 ekor/tahun dengan produksi daging 14.326 ton/tahun. Berdasarkan data tersebut ada berbagai faktor yang menyebabkan peningkatan populasi tidak diiringi dengan peningkatan produksi daging, antara lain: (1) Penurunan kualitas genetik sapi; (2) Bobot sapi potong yang disembelih beratnya lebih kecil setiap tahunnya; (3) Persentase karkas yang dihasilkan kualitasnya mengalami penurunan.

\section{KONSUMSI DAGING MASYARA- KAT PROVINSI LAMPUNG}

Gaya hidup adalah keseluruhan pola hidup seseorang yang diaplikasikan dalam aktifitas, minat, dan opini serta berinteraksi dengan lingkungannya. Menurut Suryani (2013), gaya hidup adalah pola konsumsi yang merefleksikan pilihan individu dalam hal bagaimana mereka menghabiskan uang dan waktunya. Dari perspektif ekonomi, gaya hidup lebih menunjukkan kepada cara pengalokasian pendapatan seseorang dan pemilihan produk atau jasa sebagai pilihan. Dengan kata lain, perubahan gaya hidup akan mengubah pola konsumsi seseorang. Pada sektor peternakan khususnya daging sapi perubahan gaya hidup akan berakibat pada perubahan konsumsi masyarakat terutama konsumsi protein hewani. Awalnya masyarakat hanya mengenal telur dan daging ayam maka akan berubah ke konsumsi daging. Peningkatan konsumsi masyarakat untuk mengkonsumsi daging sapi disebabkan oleh kesadaran masyarakat pentingnya mengkonsumsi makanan yang berprotein tinggi, data konsumsi daging sapi di Provinsi Lampung tersaji pada Tabel 3. 
Tabel 3 Jumlah Konsumsi Daging Perkapita (Kg/tahun) di Provinsi Lampung dan Nasional

\begin{tabular}{ccc}
\hline Tahun & $\begin{array}{c}\text { Konsumsi Daging } \\
\text { Sapi Provinsi } \\
\text { Lampung per } \\
\text { Kapita (Kg/tahun) }\end{array}$ & $\begin{array}{c}\text { Konsumsi Daging } \\
\text { Sapinasional per } \\
\text { Kapita } \\
\text { (Kg/tahun) }\end{array}$ \\
\hline 2014 & 0,1448 & 1.221 \\
2015 & 0,1743 & 1.777 \\
2016 & 0,1573 & 1.884 \\
2017 & 0,2349 & 2.551 \\
2018 & 0,1795 & 2.518 \\
2019 & - & 2.560 \\
\hline
\end{tabular}

Sumber: BPS, 2020

Berdasarkan data pada Tabel 3 konsumsi daging masyarakat di Provinsi Lampung cenderung mengalami peningkatan. Data tersebut menunjukkan pada tahun 2014-2015 konsumsi daging masyarakat Provinsi Lampung mengalami peningkatan sebesar 0,0295 $\mathrm{kg}$ /tahun per kapita setara dengan 17\% dibandingkan dengan tahun sebelumnya, sedangkan konsumsi nasional meningkat sebanyak $556 \mathrm{~kg} /$ tahun per kapita atau sebesar 31\%. Tahun 2015-2016 konsumsi daging masyarakat Provinsi Lampung mengalami penurunan sebesar $-0,017$ $\mathrm{kg} /$ tahun per kapita atau setara $-11 \%$, sedangkan konsumsi nasional mengalami peningkatan sebanyak $107 \mathrm{~kg} /$ tahun per kapita atau sebesar 6\% dibandingkan tahun sebelumnya. Tahun 2016-2017 konsumsi daging masyarakat Provinsi Lampung mengalami peningkatan sebesar $0,0776 \mathrm{~kg} /$ tahun per kapita setara dengan 33\%, sedangkan konsumsi nasional sebanyak $667 \mathrm{~kg} /$ tahun per kapita atau sebesar 26\%. Konsumsi daging masyarakat Provinsi Lampung tahun 2017-2018 mengalami penurunan sebanyak -0,0554 per kapitakg/tahun atau setara dengan $-31 \%$, konsumsi daging nasional juga mengalami penurunan -33 per kapita $\mathrm{kg} /$ tahun atau sebesar $-1 \%$.

Peningkatan dan penurunan konsumsi daging salah satunya disebabkan oleh harga daging. Harga daging sapi cenderung berfluktuasi. Hal ini karena dipengaruhi oleh tinggi rendahnya permintaan pasar. Pada bulanbulan tertentu menjelang hari besar keagamaan permintaan daging sapi akan mengalami peningkatan yang cukup drastis. Peningkatan permintaan daging sapi yang melonjak seperti ini mengakibatkan kenaikan harga yang sangat signifikan dari harga awal. Setelah selesai hari raya besar, biasanya permintaan akan daging sapi berangsur turun sehingga harga daging sapi akan mengalami penurunan sedikit demi sedikit, hingga harga menjadi stabil. Peningkatan dan penurunan permintaan tersebut mengakibatkan harga daging sapi menjadi fluktuatif (Sudarmono dan Sugeng, 2008). 


\section{RATAAN HARGA PANGAN DI POVINSI LAMPUNG}

Pangan merupakan kebutuhan yang harus dipenuhi dalam kehidupan sehari- hari. Stok pangan harus tersedia secara teratur berdasarkan permintaan dan penawaran konsumen. Tujuannya yakni untuk mencegah agar pangan tidak mengalami kehabisan stook yang akhirnya akan menimbulkan kelangkaan. Pemahaman mengenai teori permintaan sangat penting untuk dipelajari. Nasution (2006) menerangkan tentang teori permintaan dan faktor-faktor yang mempengaruhi permintaan barang dengan penjelasan sebagai berikut:

a. Harga

Kuantitas yang diminta akan menurun ketika harganya meningkat dan kuantitas yang diminta meningkat ketika harganya menurun; dengan kata lain, kuantitas yang diminta berhubungan negatif dengan harga. Hubungan antara harga dan kuantitas ini yang dinamakan hukum permintaan.

b. Pendapatan

Ketika pendapatan rendah maka secara total uang yang dibelanjakan lebih sedikit. Jika permintaan terhadap barang berkurang ketika pendapatan berkurang, barang tersebut disebut barang normal (Normal good). Jika permintaan terhadap barang meningkat ketika pendapatan turun, maka barang tersebut disebut barang inferior (Inferior good).

c. Harga barang lain yang berkaitan

Apabila penurunan harga barang satu menurunkan permintaan terhadap barang yang lain, maka kedua barang tersebut disebut barang subtitusi. Jika penurunan harga suatu barang meningkatkan permintaan baranglainnya, kedua barang tersebut disebut barang komplemen.

d. Selera

Ekspektasi atau perkiraan mengenai masa mendatang dapat mempengaruhi permintaan terhadap barang dan jasa saat ini.

e. Jumlah penduduk

Semakin besar jumlah penduduk di suatu daerah, semakin banyak permintaan terhadap suatu produk di daerah tersebut.

Selain mengkonsumsi daging, masyarakat juga mengkonsumsi beras dan protein hewani lainnya. Konsumsi pangan rata-rata masyarakat Provinsi Lampungtersaji pada Tabel 4.

Tabel 4 Rataan Harga Telur Ayam, Daging Ayam, Daging Sapi, dan Beras di Provinsi Lampung/Tahun

\begin{tabular}{ccccc}
\hline Tahun & \multicolumn{4}{c}{ Rataan Harga $(\mathrm{Rp} / \mathrm{Kg})$} \\
\cline { 2 - 5 } & $\begin{array}{c}\text { Teluar } \\
\text { Ayam }\end{array}$ & $\begin{array}{c}\text { Daging } \\
\text { Ayam }\end{array}$ & $\begin{array}{c}\text { Daging } \\
\text { Sapi }\end{array}$ & Beras \\
\hline 2014 & 18.193 & 30.343 & 98.023 & 10.750 \\
2015 & 20.001 & 31.212 & 104.986 & 10.744 \\
2016 & 20.141 & 32.150 & 116.403 & 10.595 \\
2017 & 20.289 & 32.488 & 133.160 & 10.022 \\
2018 & 22.713 & 36.895 & 134.438 & 11.060 \\
2019 & 23.666 & 33.750 & 127.188 & 10.072 \\
\hline Sumber: BPS 2020 & & &
\end{tabular}




\section{PERSENTASE PERTUMBUHAN EKONOMI PROVINSI LAMPUNG}

Provinsi Lampung merupakan provinsi strategis yang terletak berdekatan dengan ibu kota. Keadaan ini akan berdampak baik terhadap pertumbuhan ekonomi di Provinsi Lampung. Sektor ekonomi yang potensial harus dikelola dan terus dikembangkan untuk mensejahterakan semua pihak. Sektor yang masih potensial yakni sektor pakan asal ternak. Indrawati (2019) menyatakan bahwa sektor-sektor ekonomi yang berpotensial hendaknya lebih dikembangkan lagi sehingga di masa-masa yang akan datang sektor-sektor ekonomi tersebut dapat diandalkan untuk kontribusi perekonomian. Persentase pertumbuhan ekonomi Provinsi Lampung disajikan pada Tabel 5.

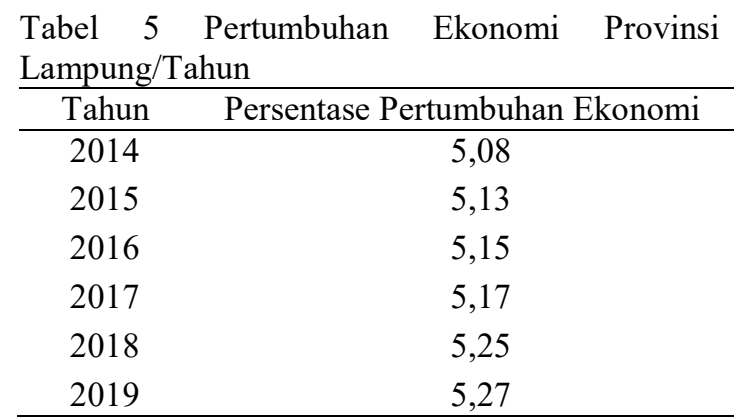

Sumber: BPS, 2021

\section{FAKTOR-FAKTOR YANG MEMPENGARUHI PERMINTAAN DAGING SAPI}

Berdasarkan hasil analisis koefisien determinasi $\left(\mathrm{R}^{2}\right)$ diperoleh sebesar 0,994 atau dengan kata lain terdapat 99,4\% permintaan daging sapi di Provinsi Lampung dapat dijelaskan oleh variabel harga daging sapi, harga daging ayam, harga telur ayam ras, harga beras, jumlah penduduk Lampung, konsumsi daging sapi di Indonesia serta pertumbuhan ekonomi di Lampung. Sementara sisanya 0,06 atau $6 \%$ dapat dijelaskan oleh faktor luar dari variabel, misalnya selera konsumen, kesadaran gizi konsumen, banyaknya penduduk tidak tetap di Provinsi Lampung, dll.

Berdasarkan hasil uji parsial atau uji $t$ diperoleh variabel rataan harga daging sapi secara individu berpengaruh signifikan terhadap permintaan daging sapi di Lampung, yaitu dengan nilai signifikansi sebesar 0,009. Hal tersebut menunjukkan bahwa harga daging sapi berpengaruh nyata terhadap tingkat kepercayaan 95\%. Koefisien regresi variabel harga daging sapi diketahui sebesar 0,000519, hal tersebut menunjukkan bahwa setiap kenaikan 1\% harga daging sapi akan menaikkan tingkat permintaan daging sapi sebesar 0,0000519\%. Harga daging yang relatif fluktuatif dipengaruhi oleh jumlah ketersediaan daging. Ketika harga daging meningkat, maka permintaan daging ditingkatkan agar harga daging sapi bisa 
menurun karena permintaan konsumen akan menurun ketika harga daging tinggi. Sebaliknya, ketika harga daging turun, maka permintaan konsumen terhadap daging akan meningkat.

Tabel 6 Hasil Analisis Uji t

\begin{tabular}{lccc}
\hline Variabel & Koef. Regresi & Uji t & Signifikan \\
\hline X1 (Rataan harga daging sapi) & 5,191 & 5,993 & 0,009 \\
X2 (Rataan harga daging ayam) & 2,192 & 1,509 & 0,228 \\
X3 (Rataan harga telur ayam) & 0 & $-4,417$ & 0,022 \\
X4 (Rataan harga beras) & 0 & $-0,497$ & 0,653 \\
X5 (Jumlah penduduk Lampung) & 0,003 & 1,575 & 0,213 \\
X6 (Konsumsi daging sapi) & $-1,993$ & $-3,797$ & 0,032 \\
X7 (Pertumbuhan ekonomi) & 3,591 & 3,769 & 0,033 \\
\hline
\end{tabular}

Sumber: Hasil Analisis Data Regeresi, 2021

Variabel harga telur ayam, variabel konsumsi daging di Indonesia serta pertumbuhan ekonomi juga mempunyai pengaruh secara individu terhadap tingkat permintaan daging sapi dengan nilai signifikansi berturut-turut sebesar 0,022, 0,032 , dan 0,033 sehingga variabelvariabel tersebut berpengaruh nyata terhadap tingkat kepercayaan 95\%. Adapun koefisien dari variabel harga telur ayam sebesar 0,000 yang menunjukkan bahwa setiap kenaikan harga telur ayam sebesar $1 \%$ akan meningkatkan permintaan daging sapi sebesar $0,000 \%$. Terjadi kenaikan dan penurunan harga telur ayam akan mempengaruhi jumlah permintaan dan permintaan daging sapi. Hal ini dikarenakan telur ayam merupakan barang substitusi dari daging sapi. Penurunan harga barang substitusi (telur ayam) akan berpengaruh terhadap penurunan permintaan dan permintaan daging sapi. Konsumen membeli telur ayam karena harga telur ayam lebih murah daripada harga daging sapi. Kebutuhan gizi protein hewani dapat dipenuhi dengan mengkonsumsi telur ayam.

Koefisien regresi dari variabel konsumsi daging sapi di Indonesia sebesar -1,993 yang menunjukkan bahwa setiap kenaikan konsumsi daging di Indonesia sebesar 1\% akan menurunkan tingkat permintaan daging sapi di Lampung sebesar 1,993\%; begitupun sebaliknya, setiap penurunan konsumsi daging di Indonesia sebesar 1\% akan meningkatkan permintaan daging sapi di Lampung sebesar 1,993\%.

Koefisien variabel pertumbuan ekonomi di Lampung sebesar 3,591 menunjukkan bahwa setiap kenaikan pertumbuhan ekonomi maka akan menaikkan tingkat permintaan daging sapi di Lampung sebesar 3,591\%. 


\section{KESIMPULAN}

Berdasarkan hasil penelitian analisis faktor-faktor yang mempengaruhi permintaan daging sapi di Provinsi Lampung, maka dapat disimpulkan bahwa faktor-faktor yang mempengaruhi permintaan daging sapi di Lampung adalah harga daging sapi, harga telur ayam, konsumsi daging sapi di Indonesia, dan pertumbuhan ekonomi di Provinsi Lampung.

\section{DAFTAR PUSTAKA}

[BPS] Badan Pusat Statistik. 2021. Provinsi Lampung dalam Angka 2021. Tersedia pada https://lampung.bps.go.id/publicati on/2021/02/26/443c020eb6a33a394 e6d3df4/provinsi-lampung-dalamangka-2021.html.

[BPS] Badan Pusat Statistik. 2020. Pola Konsumsi Penduduk Provinsi Lampung. Tersedia pada https://lampung.bps.go.id/publicatio n.html?Publikasi\%5BtahunJudul\% $5 \mathrm{D}=\&$ Publikasi $\% 5$ BkataKunci\% $5 \mathrm{D}=$ pola + konsumsi\&Publikasi $\% 5$ BcekJudul\%5D=0\&yt0=Tampilkan.

[BPS] Badan Pusat Statistik. 2020. Statistik Harga Konsumen Kota Bandar Lampung 2020. Tersedia pada https://lampung.bps.go.id/publicati on.html?Publikasi\%5BtahunJudul.

$\% 5 \mathrm{D}=\&$ Publikasi $\% 5 \mathrm{BkataKunci} \% 5 \mathrm{D}=$ ha rga+konsumen\&Publikasi\%5BcekJ udul $\% 5 \mathrm{D}=0 \&$ Publikasi $\% 5 \mathrm{~B}$ cekJudul $\% 5 \mathrm{D}=1 \&$ yt0=Tampilkan.
[BPS] Badan Pusat Statistik. 2015. Proyeksi Penduduk Kabupaten/Kota Provinsi Lampung. Tersedia pada https://media.neliti.com/media/publ ications/48755-ID-proyeksipenduduk-kabupatenkota-provinsilampung-2010-2020.pdf.

Dharmastuti D, Supardi S, Rahayu W. 2016. Analisis Faktor-Faktor yang Mempengaruhi Permintaan Daging Sapi di Kota Surakarta. Agrista 4(3): 94-103.

Dwiyanto, K. 2008. Pemanfaatan Sumber Daya Lokal Dan Inovasi Teknologi Dalam Mendukung Pengembangan Sapi Potong Di Indonesia. Pengembangan Inovasi Pertanian 1(3): 173-188.

Fatmawati, Rostin, Baso J N. 2016. Faktor-Faktor yang Mempengaruhi Daging Sapi di Indonesia. Jurnal Ekonomi 1(1): 128-134.

[KEMENTAN] Kementerian Pertanian. 2019. Buletin Konsumsi Pangan. Pusat Data dan Sistem Informasi Pertanian Sekertariat Jenderal Kementerian Pertanian. 10(1):2019.

Mahroji, D.,\& Indrawati, M. (2019) Analisis Sektor Unggulan Dan Spesialisasi Regional Kota Bandar Lampung. Jurnal Ekonomi, Bisnis dan Manajemen. 9(1), 1-8.

Sudarmono dan Sugeng. 2008. Sapi potong (Pemeliharaan, Perbaikan, Produksi, Prospek Bisnis, Analisa Penggemukan). Jakarta: Penebar Swadaya.

Talib, C dan Yudi. 2008. Penyediaan Daging Sapi Nasional Dalam Ketahanan Pangan Indonesia. Seminar Nasional Teknologi Peternakan dan Veteran. 